\title{
Inga Language and Culture Revitalization in Putumayo, Colombia
}

\author{
Valerie Cross \\ Serafín M. Coronel-Molina
}

\begin{abstract}
Increasing levels of Quechua-Spanish bilingualism and increased use of Spanish within indigenous communities and classrooms have given rise to concern about Quechua language maintenance (Hornberger, 1988, 1998, 1999; Hornberger \& Coronel-Molina, 2004). The present investigation is preliminary and explores the possibility of bilingual intercultural education to promote Quechua (Inga) language revitalization in the Putumayo region of Colombia. Because of the large role that schooling has played in the language shift process, Inga language revitalization efforts have focused on implementing use of the Inga language in schools. This paper offers suggestions based on research in second language acquisition (SLA), language revitalization, and bilingual intercultural education to improve recent efforts and overcome the many overt and covert challenges that exist to bilingual education implementation in Putumayo, Colombia. This article attempts to bring such forms of resistance to the surface and provide suggestions for overcoming them, in hopes of facilitating the grassroots-initiated language planning goals of culture revitalization and reversing language shift that are already in place.
\end{abstract}

\section{Introduction}

In the present context of cultural, economic, and political globalization, world languages with international status continue to gain perceived value, while local languages correspondingly lose value or "currency" in the global language market (McCarty, 2003). Increasing levels of Quechua-Spanish bilingualism and increased use of Spanish within indigenous communities and classrooms have given rise to concern about Quechua language maintenance (Hornberger, 1988, 1998, 1999; Hornberger \& Coronel-Molina, 2004). The present investigation is preliminary, as the authors have not yet conducted field work in the Putumayo region of Colombia. The authors draw on other Andean and bilingual research to explore the possibility of bilingual intercultural education to promote Quechua language revitalization in the Putumayo region of Colombia. More specifically, the paper is an attempt to portray the present linguistic and educational situation of Colombian Ingas, as well as to outline forms of resistance and possibility of bilingual Inga-Spanish education in Putumayo.

Following a brief overview of Quechua language shift, this paper focuses on the Inga context in Colombia. The historical role of schools in Inga communities, including their influence on language shift from Inga to Spanish, will then be addressed. Because of the 
large role that schooling has played in the language shift process, Inga language revitalization efforts have focused on implementing the use of the Inga language as a medium (versus as a school subject) in schools. The present paper focuses on the resulting bilingual education efforts in Putumayo, Colombia, highlighting some potential impediments in the present program and curricular design as well as various other forms of resistance to the efforts. Suggestions are made to improve the present bilingual education situation based on second language acquisition (SLA), language revitalization, and bilingual intercultural education research. While we acknowledge that there exist many overt and covert challenges to bilingual education implementation in Putumayo, this paper attempts to bring such forms of resistance to the surface and provide suggestions for overcoming them in hopes of facilitating the grassroots-initiated language planning goal of reversing language shift.

\section{Quechua Language Shift}

In the midst of comparable histories that include resisting years of European colonization attempts, similar experiences and challenges have emerged across diverse Quechuaspeaking communities. One such challenge has been the function of Spanish as a significant tool of colonization and its status as the national language of many of the countries where indigenous communities reside (Coronel-Molina, 1999, 2007; Hornberger, 1987). Language has served as an important means of preservation of Quechua culture and civilization as well as resistance against colonizing forces (Carlosama Gaviria, 2001). In the context of increased contact with the Spanish language in the last five centuries, trends of language shift toward use of Spanish and bilingualism have become increasingly prevalent (for a comprehensive definition and literature review of language shift, see Coronel-Molina, 2009).

Within many Quechua communities, Spanish is commonly learned at a young age, resulting in high levels of 'bilingualism,' understood here as native-like productive and receptive command of two languages. Generational differences in the occurrence of bilingualism among indigenous persons are vast and increasing in the context of recent escalation of contact with nonindigenous national populations, due to immigration as well as other factors (Coronel-Molina, 1999; Harvey, 1994; Hornberger, 2000). Quechua language maintenance has become an issue of concern in light of the recently increasing rates of language shift away from Quechua (Hornberger, 1988, 1998, 1999; Hornberger \& Coronel-Molina, 2004).

\section{Colombian Inga Context \\ Present Linguistic Reality}

According to Colombia's 2005 census (DANE, 2005), of Colombia's 41,468,384 total population, about $3.4 \%$ or $1,392,623$ are considered ethnically indigenous and represent a vast diversity of indigenous groups. According to DANE (2007), 64 American Indian languages are spoken in Colombia, representing 13 language families. Inga is one such language, and is spoken by Ingano populations found mostly in rural areas in and around the Putumayo department of southwest Colombia as well as in urban areas such as Bogotá. The ethnic population of Ingas is approximately 17,860, and the Inga language is one of 
many dialects of Quechua (Ethnologue, 2005). Inga, also known as Highland Inga, is spoken by approximately 16,000 people, 12,000 of whom reside in Colombia, mostly in and around the department of Putumayo in Colombia (Ethnologue, 2005). Ingas and other indigenous groups represent $21 \%$ of the total population in the department of Putumayo (DANE, 2005). Despite the laws that have been passed to protect the rights of indigenous languages, Spanish continues to be the official language in the state institutions of Colombia (Education Project, 2003).

\section{Inga Language Shift in the Putumayo Region}

Soler Castillo (2003) investigated degrees of bilingualism and indigenous (Inga) attitudes toward Spanish and the Inga dialect of Quechua in the rural Inga town of Santiago in the department of Putumayo, Colombia and in the urban area of Santafé in the department of Bogotá, Colombia. The comparison of these two locations resulted from hypotheses that the Ingas in Bogotá, most of whom migrated from Santiago, are losing their language and culture at an accelerated rate compared to their rural counterparts due to the increased contact with the city culture. In her research, Soler Castillo found similar generational trends in command of the Inga language in both locations. The adults (older than 26) are fully bilingual Inga-Spanish, and the youth (15-25 years) and children (9-14 years) are not considered fully bilingual because though they have good comprehension of Inga, they speak it infrequently. Adults have proficiency in both languages but prefer to speak Inga in the majority of contexts, and younger members prefer to use Spanish in almost all contexts. Despite the stark generational division in bilingualism and language use found among Inga Quechua speakers of these communities, Soler Castillo describes the general linguistic attitudes toward both Inga and Spanish as very positive across ages.

The recent shift toward use of Spanish over Inga in various contexts reflects political and cultural pressures and may be cause for concern in terms of Inga language preservation. Social dynamics and language choice are complicated even further for the many Ingas that migrate to urban areas in search of work (Soler Castillo, 2003). Due to greater contact with Spanish speakers, Inga families living in urban areas communicate mostly in Spanish or a form of Inga laced with Spanish loan words and syntax, whereas those in rural areas have a tendency to communicate in Inga (Education Project, 2003). Within families with higher education levels, as well as in families with one nonindigenous parent, Spanish tends to be the primary language spoken. Inga children raised in a household in which they have extensive contact with the grandparents or elders of the family have the highest probability of growing up bilingual (Education Project, 2003).

\section{Role of Schooling in Inga Language Shift}

The shift in language use from Quechua to Spanish is especially evident upon examination of the use of the two languages within indigenous classrooms. Schooling in colonial contexts is one specific domain where the dominant language is often instantiated at the expense of the indigenous languages present in the society (Coronel-Molina, 1999, 2007). Schools run by members of the colonizing society have historically served as a tool of colonization and have played an important role in promoting language shift toward the language of colonization (Carlosama Gaviria, 2001; Hornberger, 1987). Carlosama Gaviria (2001) describes the instantiation of schooling by members of the dominant, colonizing 
population as a tool of submission and integration of indigenous groups into the majority society. He claims that this colonizing attempt is realized through methods and strategies aimed at ridding indigenous pupils of their cultural identities in favor of adoption of the national majority culture, which is thought or claimed to be more civilized.

In light of the sociohistorical context of many indigenous populations, one can understand more completely the role that schools have historically had, and the embedded ideologies and expectations of the role of schools within communities. As most schools in these particular Quechua communities were founded for the sole purpose of teaching community members Spanish and were to be maintained as separate entities from the rest of the community, it is not surprising that all teaching has historically been conducted in Spanish and the school is ideologically and physically positioned on the periphery of the community. As has been observed in other Andean and non-Andean language revitalization contexts, such positioning can negatively affect student learning and deter indigenous community member involvement in education and curriculum planning affecting indigenous children (García, 2005; Harvey, 1994).

Schools in Inga communities in the Putumayo Valley of Colombia are no different from those highlighted above, having long been associated with colonization. Educational institutions have contributed to the hegemony of the Spanish language within the indigenous communities of Colombia. In the case of the Inga communities in the Putumayo region, the mission of assimilation has been enacted through boarding schools in which teaching is exclusively in Spanish, children are separated from their families and culture, and use of traditional Inga dress and the Inga language have been prohibited and replaced by mainstream Spanish language and culture (Education Project, 2003). As outlined by Fishman (1991), attempts to distance indigenous students from their culture can be a powerful tool in reducing symbolic power and agency, especially coupled with banning use of the native language (Bourdieu 1991). Schooling historically based on colonization and taught by nonindigenous outsiders had and continues to have many important implications for language medium and classroom curricula. As Carlosama Gaviria (2001) asserts, teaching in Colombia has been based on one model with the objective of "civilizing" and instructing the "Indian" about how to integrate into the national society.

Within the context of varying levels of bilingualism, both indigenous and nonindigenous teachers in Inga schools use Spanish as the mode of instruction. The Inga students from rural communities who do not know Spanish are at an early disadvantage in the Spanish-dominated educational system. As Hornberger (2006) points out based on research with Quechua communities in Puno, Peru, attribution of a naturally shy and reserved personality to Quechua children discounts and veils the possibility that these children may be quiet in the classroom due to the language barrier that many experience. The early disadvantage is evident in the frequent obligation of Inga-speaking students to repeat primary grades, especially the first year of school (Education Project, 2003). While some of these students do learn Spanish as a second language eventually (at least oral communication skills), the early schooling experiences in a language they do not understand coupled with the demand that they repeat grades are likely to contribute to negative school attitudes and a high drop-out rate. The frequent occurrence of early dropout among Inga schoolchildren may be reflected in the drastically higher population of 
students in the first grade (more than 100) and relatively few students enrolled in the sixth grade or beyond (less than 20) (Education Project, 2003).

\section{Language Revitalization}

Language policy and planning (LPP) efforts have been explored and theorized by many scholars in a variety of contexts (Canagarajah, 2005; Cooper, 1989; Fishman, 1991; Hinton \& Hale, 2001; Kaplan, 1994; Kaplan \& Baldauf, 1997; McCarty, 2011; Ricento, 2006, among others). Concern about language shift and death, and the possibility of reversing language shift and of revitalization of endangered languages have become a major focus in LPP research (Crystal, 2000; Fishman, 1991; Grenoble and Whaley, 2006; Hinton and Hale, 2001). Following Coronel-Molina's $(1999,2007)$ framework of language shift in particular social domains, language revitalization is defined by King (2001) as "the attempt to add new linguistic forms or social functions to an embattled minority language with the aim of increasing its uses or users" (p. 23). This notion of revitalization of languages that have been threatened or partially lost implies a situated context of multiple languages assigned unequal degrees of power or status. For these reasons, indigenous language planning must also incorporate planning for the other, often "dominant" language(s) present in the context (Hornberger, 2006; Karam, 1974). In contrast to the notion of language maintenance, which focuses more on maintaining and strengthening immigrant and indigenous languages, language revitalization requires deliberate efforts by the speakers of the language and tends to originate within the speech communities (Fishman, 1991; Hornberger, 2006). Hornberger and King (1996) also emphasize the necessity of involvement of present and future speakers of a language in the process of indigenous language revitalization, an involvement that must also be present in the implementation of multilingual education in indigenous contexts (see also Hornberger, 2006).

\section{Inga Language Revitalization}

Inga language revitalization efforts have emerged largely from the grassroots level, and the community-level concerns about reversing language shift and revitalizing the Inga language have been inextricably linked to cultural revitalization concerns. Also, language revitalization efforts in the Putumayo have centered around the incorporation of Inga in the community schools. For that reason, it is logical to examine the history of the efforts to change the schooling context along with the accompanying national policies that have supported these efforts. Cultural revitalization efforts will also be briefly addressed, followed by a section including a more critical examination of the bilingual education efforts in the Putumayo.

In the 1970s and 1980s, grassroots movements involved people within the Inga community voicing a need to establish their own educational system, one that is culturally relevant for indigenous students and which incorporates the Inga language in the curriculum. Musu Runakuna ("New People") is among the indigenous organizations that have called for research and support for improving education within their communities, and specifically for the incorporation of Inga in community schools (Tandioy Jansasoy, personal communication, November 3, 2008). This is often referred to as "etnoeducación" (ethno-education) in Colombia, and as Educación Intercultural Bilingüe ("Intercultural Bilingual Education") in other Spanish-speaking countries (Carlosama Gaviria, 2001). 
Addressing the lack of native Inga teachers and consequently the need for preparation of indigenous teachers followed.

Following the grassroots demands for educational policy change, the national government of Colombia passed numerous laws supporting indigenous education. The General Law of Education (Law 115 in 1994) in Colombia, which followed the Constitutional Reform of 1991, and Decree 804 (1995) provided an impetus for supporting improved education in the indigenous communities of Colombia (Ministerio de Educación Nacional, República de Colombia). The need and desire for educational improvements in indigenous communities, particularly in the Inga communities of the Sibundoy Valley, are clearly evident, but actual change and development is still in the beginning stages.

\section{Inga Culture Revitalization}

Underlying the possibility of language revitalization must be a unified community consciousness of the endangered status of the language, and efforts to revitalize must be initiated at the grassroots level (Coronel-Molina 1999, 2005, 2007; Hornberger \& King 1996, 1998, 2001). Grassroots support seems to be dependent upon a valuing of not only the indigenous language but also of the group's cultural practices. Fishman (1991) describes cultural dislocation as a disruption of traditional cultural practices often resulting in a decrease in collective control in communities. As previously mentioned, Fishman (1991) asserts that along with social and physical/demographic dislocations, cultural dislocations can contribute to a complicated language shift process resulting in the reduction of power and agency (Bourdieu, 1991). Because of the intricate link between indigenous language and cultural identity (Coronel-Molina \& Quintero, 2010; Hornberger, 1988; Hornberger \& Coronel-Molina, 2004; Howard, 2007; King, 2000), inherent in language revitalization (and multilingual education) efforts must be the promotion of valuing indigenous cultural practices and identity.

As mentioned above, Inga language revitalization concern and efforts are linked to cultural revitalization, with their success possibly interdependent. In this way, a precursor for success of bilingual programs which promote the teaching of Inga language and culture is promotion of Inga cultural revitalization. While national laws that promote and celebrate the ethnic diversity of Colombia abound, indigenous groups still experience much discrimination. Soler Castillo (2003) discusses the discrimination that Ingas experience in schools and communities in urban areas like Bogotá. On the grassroots level in both urban and rural communities, appreciation of the Inga culture must be shared in the face of globalization and the presence of national culture, before unified community support of bilingual education can flourish. This Inga cultural renaissance or revitalization has been promoted by various indigenous leaders and groups. The Musu Runakuna group has been instrumental in promoting the rights of Ingas and in renewing Inga cultural traditions within communities in the Putumayo since the 1980s (Tandioy Jansasoy, personal communication, November 3, 2008). In addition to petitioning the government and working for political rights, the Musu Runakuna has consulted elders of the community about cultural traditions which they have worked to restore. Along with cultural revitalization efforts, pockets of grassroots language planning efforts have emerged to promote Inga language education. 


\section{Bilingual Intercultural Education}

As schooling is one important domain which has been instrumental in promoting language shift away from indigenous language use in societies, the possible role of schools in promoting indigenous language revitalization must be considered (Hornberger, 2008; Hornberger \& King, 1996). With the prevalence of Spanish in the broader community and perception of a higher market value of the language, it is not surprising that the belief in the importance of Inga children learning Spanish is widespread. It has been observed that most Ingas who do learn predominantly through Spanish in school use Spanish more than Inga, and are usually lacking in both Inga and Spanish academic literacy and skills. The need for Inga to be used in schools serving Inga children has been established also, and a push for Inga-Spanish bilingual education in the Putumayo has surfaced.

Thus far, one Inga-Spanish bilingual school has been established in the Putumayo region, in the town of Santiago. The school is situated in a town where there have historically been two schools, one for girls run by nuns and another for boys run by the Maristas (male Catholic headmasters), both of which are still in place and serve many nonindigenous as well as indigenous students. The bilingual school was implemented within the last five years and is called "Ingapa wasi Carlos Tamoabioy," translated as "The Carlos Tamoabioy Ingas' School." The school currently serves about 70 students, male and female, in grades one through five, with the goal of extending the school to provide education through grade nine in the near future. The curriculum follows a typical transition model including a gradual progression from total Inga instruction in grade one to nearly total Spanish instruction in grade five. Spanish is first introduced in grade two, and instruction is to be 50 percent in both Inga and Spanish in grade three, followed by a decrease in use of Inga in grades four and five (Tandioy Jansasoy, personal communication, November 5, 2008).

Still, bilingual education efforts in the Putumayo seem to fall short of producing students with high levels of bilingualism or academic skills in either or both languages, perhaps due to insufficient support of Inga literacy, among other factors. Arguments based on second language acquisition principles claim that the development of both languages, including academic proficiency in them, would be better supported with a bilingual education program that provides adequate Inga L1 support in the classroom throughout schooling. While Spanish may continue to be used more in some domains, the subsequent increases in Inga interpersonal and academic language skills that students would obtain through schooling would likely contribute to the maintenance of the language.

In the next section, program design considerations are presented. Challenges and some possible solutions to Inga-Spanish bilingual education components including program design, materials development, and teacher training will be addressed. Second language acquisition research supporting the need for L1 academic support throughout bilingual schooling efforts will be presented, followed by intercultural bilingual education program types. Suggested program improvements are aimed at increasing the possibility of bilingual education to reverse language shift and contribute to Inga language revitalization. 


\section{Program Design Considerations}

\section{Supporting L1 Academic Literacy in Bilingual Education}

The assumption that academic literacy, known as Cognitive Academic Language Proficiency (CALP), is distinct from general communicative language development or Basic Interpersonal Communication Skills (BICS) is important for understanding language development via schooling (Cummins, 1981). Unlike the language used in informal interpersonal communication, formal language in oral and written academic classroom tasks is thought to require the generation of more complex syntax, more cognitively demanding manipulation of language, and less contextual support (Chamot \& O'Malley, 1994; Cummins, 1982; 1996; Wright \& Kuehn, 1998). According to this distinction, a student can develop interpersonal communicative skills in a second language but not develop the academic skills in that language necessary for high academic achievement. Researchers also seem to agree that the ability to understand and use academic language in the classroom positively correlates with student academic achievement in both the L1 (first language) and L2 (second language) (Chamot \& O'Malley, 1994; Collier, 1989). In the Inga example, just because a student learns Spanish communicative skills through schooling does not necessarily mean that the student will develop academic skills in Spanish.

Much research attests the importance of developing academic language proficiency in the L1 before learning it in the L2, and also demonstrates that academic skills or language learned through the L1 easily transfers to the L2 (Eisterhold Carson et al., 1990; Holm \& Dodd, 1996; Jiang \& Kuehn, 2001). If this research is substantiated, it would imply that Inga students would benefit more from beginning their schooling in their native Inga language and continuing to develop academic skills through Inga even when Spanish is added later. Previous experiences with literacy and schooling in the L1 logically affect students' potential in the development of L2 academic literacy. From early literacy experiences (presumably in the L1), children develop attitudes toward literacy, beliefs about what literacy entails, and strategies for learning literacy skills (Carson, 1992; Carson et al., 1990). These early experiences can transfer to literacy development in the L2 (Holm \& Dodd, 1996), or at least equip students with tools and resources to draw on in the development of literacy in a new language. Cummins (1989) found correlations between L1 and L2 academic proficiency to range from .60 to .80 and demonstrated that students' ability to read in the first language predicted their L2 reading ability. Although this only demonstrates a correlation, the implications are supported in further research.

In a study of a bilingual program for Navajo speakers in the US, students learned to read first in Navajo in kindergarten through grade 2, were then introduced to reading in English, and continued thereafter to have instruction in both Navajo and English (Rosier \& Farella, 1976). When compared with Navajo students who had only received academic literacy instruction in English, the students who learned to read first in Navajo outperformed the others in academic achievement in the English L2 more in each successive grade level and approximated national norms in English academic achievement by sixth grade. The cognitive development and content knowledge students have developed and continue developing in the L1 benefit these students when they are learning academic literacy in the L2. In addition to previous L1 academic literacy experience, the amount of continued L1 academic literacy development while learning the L2 also directly affects 
ultimate L2 academic literacy attainment (Jiang \& Kuehn, 2001; Lewelling, 1991; Swain, 1981).

The benefit of continued cognitive development that usually occurs with L1 support in the L2 classroom accounts for much of the L1 to L2 academic literacy transfer that has been observed (Bialystok, 1991; Collier, 1987, 1989, 1992; Collier \& Thomas, 1989; Cummins, 1981, 1991; Thomas \& Collier, 1995). Saville-Troike (1998) describes transfer as "a preexisting knowledge base for making inferences and predictions" (p. 5). According to this definition, it is logical that previous and continued cognitive development in the L1 in second language learning contexts impacts the potential for highly proficient L2 development. The importance of the opportunity for students in second language learning contexts to continue cognitive development through the L1 while learning the L2 has been highlighted in previous research. Among this research are studies supporting the idea that students may experience cognitive deficiencies in the L2 if their L1 language and literacy does not reach a certain threshold (Collier, 1987; Collier \& Thomas, 1989; Cummins, 1981, 1991; Thomas \& Collier, 1997). This claim is supported by researchers who attest that cognitive and academic development in the L1 can transfer to second language development (Collier, 1989, 1992; Genesee, 1994; Thomas \& Collier, 1997). If opportunities for continued cognitive development through the L1 are few or nonexistent in L2 academic learning, the cognitive and academic development that transfers to the L2 will be significantly diminished.

Many also assert that L1 content and conceptual knowledge can translate easily to the L2 when enough proficiency is attained in the language-another reason for the observed academic literacy transfer effect from L1 to L2. These claims would logically predict that continuing the development of content knowledge in the L1 while L2 proficiency is still limited will aid students in understanding complex concepts in the L2 later. This idea is tied to the cognitive development argument because when students are discouraged from drawing on and continuing development of background subject knowledge in their L1 while their L2 proficiency is developing, as with cognitive strategies in their L1, development in this arena is essentially delayed until the student gains more L2 proficiency (Collier, 1995). Hakuta (1990) presents the example that a child learning about velocity in Spanish should be able to transfer this knowledge to English without having to relearn the concept when provided with the necessary English vocabulary.

L1 literacy effects on L2 development may be delayed in the sense that they are not observable until a certain level of L2 proficiency is attained. Collier (1995) emphasizes that the complex cognitive development, background subject knowledge, and academic literacy skills learners have developed in their L1 will not show immediately in the L2, but rather with time as their L2 proficiency and literacy skills develop. This would be an example of positive L1 transfer. The lack of such skill and literacy development in the L1 would logically be predicted to lead to negative transfer to the L2, which would also be expected to surface later. Indeed, Collier (1995) reports that L2ers with limited L1 academic and cognitive development being schooled in a second language for part or all of the school day often do well in early grades (K through 2 or 3 ) but have trouble keeping up academically as the cognitive demands increase with successive grades. The disadvantages of lack of L1 development may go largely unnoticed until students reach higher levels of schooling or 
more academically challenging tasks, at which time the prospect of gaining highly developed L1 literacy will have been dramatically reduced. A strong case for the theoretical benefits of continued L1 academic literacy development deriving from students receiving some or all of their schooling through their L1 has been made. Suggestions for carrying out this claim in Inga-Spanish bilingual education with regard to program types will now be addressed.

\section{Bilingual Education Program Types}

Based on Hornberger's (1991) description of bilingual education models and program types, King (2004) discusses the two main models of bilingual education that have been implemented in South America. Programs designed primarily for indigenous students are referred to as "transitional models" based on the notion of using instruction in the L1 prior to or along with Spanish to transition students to L2 Spanish development. Arguments in support of these programs which utilize L1 instruction are that they better engage students with the school curriculum and support biliteracy development, which in turn promotes equality in the wider national society. However, such programs have also been criticized for promoting a "subtractive form of bilingualism" due to their heavy orientation towards transitioning the students to the use of Spanish, perhaps at the expense of their indigenous L1. Often in this educational environment in which Quechua is the L1 and Spanish is the L2, teachers emphasize Spanish acquisition, which supports a shift toward the dominant language and national culture.

"Enrichment" models of bilingual education describe the programs typically provided for high status or "elite" nonindigenous Spanish speakers in which usually English as a Foreign Language (EFL) is taught as the L2, and sometimes even used as the mode of instruction. These programs have been primarily reserved for nonindigenous populations and are said to be additive, in the sense that students learn an L2 viewed as a high status language as a means to enrich the students' educational and social opportunities. King (2004) claims that the approaches of the transition and enrichment models leave indigenous students with fewer educational opportunities, and describes a new bilingual education initiative implemented by an Ecuadorian indigenous group which incorporates aspects of the enrichment model in schools for indigenous students. The educational changes that have taken place in this Ecuadorian community resulted from localized planning by members within the community where language shift toward Spanish has resulted in most children being monolingual Spanish speakers. The objective of the new educational system is for indigenous (Quechua) speakers to attain a form of additive bilingualism like that offered in the nonindigenous elite schools via instruction of their heritage Quechua language as a second language. King argues that the new approach to bilingual education, along with language planning at the local level, provide the highest possibility for endangered language survival in the context of globalization threats.

The present curriculum model in the bilingual school in the Putumayo more closely resembles the transitional model, proceeding gradually from $100 \%$ in Inga to $100 \%$ in Spanish (Education Project, 2003). Inga is proposed to be used as the predominant language of instruction in grade one, followed by the introduction of Spanish in grade 2, instruction half in Spanish and half in Inga in grade 3, then a gradual decrease in Inga until 
only Spanish is used in grade 5 instruction. The curriculum here does not support L1 literacy development throughout schooling as the research suggests, which may hinder students' ultimate academic literacy achievement in both the L1 and the L2, as has been suggested. Also, the promotion of Inga language maintenance by the present model is questionable at best, and more enrichment-type models may be both applicable and beneficial to bilingual education initiatives in the Putumayo.

\section{Proposed Changes to the Inga-Spanish Bilingual Program}

According to the research presented in the previous section, Inga students would benefit from a bilingual program in which they begin their schooling in Inga and continue to develop academic literacy in Inga throughout the schooling process. After two years of schooling in Inga only, students could benefit from adding part of their schooling through Spanish, at which time their prior Inga academic literacy will be able to translate to Spanish. When their Spanish interpersonal communication proficiency has reached a certain threshold after three or four years, students should demonstrate higher academic literacy and achievement in both languages. In this way, students are able to maintain their native Inga language while simultaneously developing academic proficiency in Spanish, a characteristic of an enrichment-type program model.

Another consideration in the Inga context is total years of schooling offered. The proposed program may be more attuned to a system of schooling through grade 9 or higher, another change that has been proposed by the Inga bilingual education activists. In similar contexts, for example in Peru, where children generally do not stay in school past grade 5, indigenous parents have resisted bilingual education efforts in which Spanish is not introduced until grade 2 or 3 because of the low ultimate achievement students reach in Spanish. For this reason, until Inga-Spanish bilingual schooling is extended through grade 9 it may be beneficial to offer some Spanish as a second language instruction beginning in grade 1. Development of Inga and Inga-Spanish materials would be necessary for the implementation of this type of program and has proven difficult thus far. Materials development is one of many challenges to be addressed in the Inga context of bilingual education efforts.

Situated within a sociohistorical context in which many indigenous and nonindigenous members alike had long maintained the language ideology of the inherent superiority of Spanish over Quechua for academic purposes, the local language planning initiatives have met with resistance common to language revitalization efforts in similar contexts (Coronel-Molina, 2007, 2008; King, 2004). King (2004) highlights three common challenges faced by efforts to implement enrichment heritage bilingual education in indigenous communities: methods and materials development, reaching consensus about the dialect to be used in instruction, and attaining unity in language ideology and support across community members. The challenges of bilingual materials development and unity in community support in the Putumayo will be addressed in the next two sections. Examples of bilingual education efforts in Ecuador and Bolivia will be highlighted as examples which may shed light on possible avenues for Inga education in the Putumayo. 


\section{Bilingual Materials Development}

The development of materials and implementation of pedagogical methodology that is culturally relevant for Inga students, as well as resources for teachers, are important for implementing a bilingual education curriculum. Having materials in Inga and bilingual Inga-Spanish is critical for carrying out the suggested program design. In addition to maintaining some teaching in the students' native Inga language, the integration where possible of aspects of students' native cultures can also aid L1 and L2 literacy development by allowing students to draw on background knowledge from their native language and culture. Incorporating Inga culture in the education materials will not only facilitate the learning of language and academic literacy skills, but will also promote the valuing of Inga culture, an important part of the language revitalization process. Many communities and curriculum designers serving language minority students or seeking to produce bilingual students have realized the importance of incorporating native cultural elements and forms of knowledge into language or general education.

Some Inga community members have recognized the need to incorporate the Inga culture into bilingual education materials. One such instance is the case of Francisco Tandioy's project at Indiana University of creating an Inga-Spanish book based on Inga oral narratives. The other principal materials that have been created at Indiana University with Tandioy's help are a collection of units to teach the Inga language primarily through grammatical points and dialogues. This set of language lessons, translated from Inga to English and from Inga to Spanish, and designed to teach Inga as a foreign language to university students in the US, may not adequately serve Inga students at the primary level in Colombia. While the teachers and parents of the community seemed to receive these pedagogical materials well, many also expressed the need for more pictures and less writing to make it more suitable for the children (Tandioy Jansasoy, personal communication, December 18, 2008). Tandioy agrees and hopes to amend these materials, as well as create more materials in both Inga and Spanish based on Inga mythology, stories, and narratives. Of course, such materials development necessitates time and financial support. Lack of financial backing for such efforts has remained a powerful form of resistance to the implementation of Inga-Spanish bilingual education.

The case of Maori immersion in New Zealand demonstrates an extreme example of basing education on heritage linguistic and cultural knowledge and respect. A critical element of the success of the Maori immersion program described by Harrison (2005) is the support and contributions of the local Maori community for the program. Despite the constraints placed on the curriculum standards by the national Ministry of Education, the Waikato-Tainui tribal leaders used their constrained power to create an alternative credit system and incorporate a tribal knowledge base in the curriculum. Students observed tribal ceremonies, took field trips to important historical and cultural sites, and became experts in a tribal knowledge base determined by tribal community leaders and parents of the students. Although the context varies greatly from that of the Ingano context in Colombia, the completely functional bilingual and bicultural individuals that have participated in the program demonstrate the potential benefits of providing both native language and native culture support in schools. 
In her study of a Quechua-Spanish bilingual rural school in the department of Cochabamba in Bolivia, Hornberger (2006) observed a then-relatively new biliteracy curriculum established under the Bolivian National Education Reform of 1994. Some of the books provided by the Reform for every primary classroom include six "Big Books" in Spanish (with large pages and colorful illustrations), three of which are based on indigenous (Quechua, Aymara, and Guarani) oral traditions (p. 285). These L2 materials that incorporate indigenous cultural content are an example of contextualized material design, which can promote biliteracy development of indigenous students. "Given that, in the Bakhtinian sense, an individual develops a sense of self through incorporating the languages, dialects, genres, and words of others to which she has been exposed, this biliterate practice offers a familiar voice for indigenous children to incorporate in their own voices" (p. 286). This example provides support for the possibility of incorporating culturally relevant materials and curricula in indigenous schools which promotes both Quechua and Spanish literacy and the Quechua language, and could be applied more directly to the Inga context. Not surprisingly, such a practice is a contentious one that may be resisted by both indigenous and nonindigenous members who reject the merging of indigenous content with the Spanish language (Hornberger, 2006). (For more information about indigenous education in Bolivia, see López, 2005; Albó, 1995, 1999; Albó \& Barrios Suvelza, 2007. For bilingual education in Latin America, see López, 2006; López \& Rojas, 2006; López \& Sichra, 2008).

Much resistance to bilingual education efforts emerges at the national level in explicit forms such as unsupportive policies, or in implicit forms such as lack of financial backing of policies. In the case of the Sibundoy Valley, for example, bilingual education endeavors, including bilingual materials development in particular, are greatly hindered by the scarcity of financial support which oftentimes has been promised but not provided, or not well distributed, by Colombia's national government (Tandioy Jansasoy, personal communication, October 9, 2008). Some national government funding has been provided for the bilingual education project, and presently supports the salaries of the three indigenous teachers. Funding is insufficient, however, to adequately support bilingual Inga-Spanish material design and production. Insufficient funding serves as a form of resistance against bilingual education efforts, but may be overcome by bottom-up indigenous efforts of language planning. Such language planning is taking place within a group of Inga teachers and leaders from the town of Santiago who are dedicated to the promotion of biliteracy development of Inga students and the revitalization of the Inga language.

With the collaborative goal of producing fully bilingual and bicultural individuals with high levels of L1 and L2 literacy, curriculum design and language of medium must be carefully planned in designing a program that adequately serves the bilingual needs of students. Incorporating knowledge from the minority cultural background of the students can make the curriculum more accessible and relevant to students' experience, and promote valuing of the native culture. Also, the programs most successful at producing biliterate individuals assume that bilingual education works best when students' L1 is developed first or simultaneously with the second language, as in the Maori immersion and Bolivian Quechua-Spanish bilingual education examples. In addition to program design and 
material development considerations, community support for bilingual education efforts and bilingual teacher training are critical elements to consider.

\section{Community Support and Teacher Preparation}

Individual and often community-wide resistance to the introduction of Quechua as a mode of classroom instruction also persists in the department of Putumayo, greatly diminishing the success of bilingual education initiatives within and across communities. Resistance to restructuring the traditional curriculum in favor of a new system created by and for Inga people has been evidenced to varying degrees within different towns of the community. This lack of unity in a desire to change the educational system among the Inga towns has helped to perpetuate the traditional colonial-based system in which Spanish dominates as the mode of instruction in classrooms. Resistance toward a system of education created by Inga members can be seen in the rejection of the Inga education project (2003) proposal which was written by a group of indigenous teachers and leaders from the towns of San Andrés and Santiago, and submitted to the MEN in 2003 (Tandioy Jansasoy, personal communication, October 9,2008 ). The MEN refused financial support of the project on the grounds of insufficient funds available for distribution. Teachers-both indigenous and nonindigenous - and leaders, including Spanish priests, in other Inga towns also rejected the proposal, which was designed to apply to all Inga towns. Opponents expressed the desire to be in control of their own educational system and reserve their right to maintain the "traditional" (i.e., Spanish-based) educational system in their communities (Tandioy Jansasoy, personal communication, October 9, 2008).

Nonindigenous teachers commonly believe that there is no need for the Inga students to learn their own language, and they have been able to enforce this belief through the power assigned to them via membership in local and national teachers' unions (Tandioy Jansasoy, personal communication, October 9, 2008). Some indigenous teachers often resist a shift toward teaching in Inga (and teaching the Inga language), citing as the main reason the paucity of teaching materials in Inga and the abundance and accessibility of materials in Spanish. The creation of new materials and an overhaul of the traditional system may be seen by many as unnecessary and difficult due to a lack of resources and training on curriculum and materials development within Inga communities. Perception of a need to change the current educational system as well as sufficient means for training and materials seem to be prerequisites for the possibility of enacting a restructured curriculum in the Inga community schools.

The program of education and preparation of indigenous teachers in the Putumayo region was initiated by the Ministry of Education of Colombia in 1992 to fulfill constitutional mandates to support and develop indigenous education (ethno-education). By 2001, however, there were still no published reports about the program (Carlosama Gaviria, 2001). Indigenous teacher training in the Putumayo is still very much in the beginning stages of development, but has been addressed in literature by Carlosama Gaviria (2001) and in a collaborative educational project proposal for the creation of a bilingual intercultural educational institute submitted (but not approved) in 2003. Carlosama Gaviria (2001) continued a project started in 1990 by the MEN in which he investigated education and teacher preparation within the Inga department of Santiago in 
the Putumayo region of Colombia. The Musu Runakuna and other indigenous leaders are still working on developing the initiative to provide opportunities for Inga community members to receive quality teacher training (Tandioy Jansasoy, personal communication 2008). In addition to the training that many teachers receive at the normal schools in Colombia and elsewhere, additional training with regard to language acquisition and bilingual materials development and use would also contribute to the proposed bilingual education program reforms.

\section{Conclusion and Future Directions}

Language shift from Inga to Spanish has been an increasing reality in the Putumayo in recent decades. The education of Inga children mostly in Spanish by typically nonindigenous teachers who do not speak Inga has undoubtedly contributed to the shift. The accompanying lack of schooling through the native Inga language has also likely deprived Inga students of the possibility of developing literacy and academic skills in Inga or Spanish. The present paper is an attempt to show the current educational situation of the Colombian Inga children, including recent grassroots efforts to implement IngaSpanish bilingual education.

Bilingual education is in the early stages of development in the Putumayo Valley, and its future will depend on many factors analogous to those that have been observed repeatedly in implementations of bilingual education in other indigenous contexts. Challenges associated with indigenous bilingual education initiatives in the Putumayo Valley of Colombia abound, and increased support at both the national and local level is a precursor for more unified bilingual education implementation. Provision and success of bilingual programs in the Putumayo will continue to be influenced by national governmental support as well as support from community members in towns where biliteracy practices are implemented. Beginning with increased consciousness of the importance of revitalization and promotion of Inga language and culture within and among Inga communities, overturning long-established colonial educational practices in favor of indigenous-driven biliteracy education can and hopefully will be made possible.

Drawing on research from language revitalization, bilingual intercultural education, and second language acquisition, suggestions for improving bilingual education program design, materials, and teacher training in the Inga Putumayo context have been presented. Along with sources of resistance and suggestions for overcoming them, acknowledgement of the importance of a unified grassroots support for intercultural bilingual education initiatives as a precursor for success has been made. For schools in the Putumayo to possibly reverse language shift, teachers, parents, and community members must be unified in their support for the educational initiatives, and should be well informed about program and materials designs with the best chance of producing bilingual, academically proficient students. Ethnographic research in the Inga context could present a more grounded examination of the complex situation concerning language shift, language policy and planning, and the planning and implementation of bilingual education in the Putumayo. Future planning and implementation efforts should be coordinated with the parents, elders, and teachers of the communities in the Putumayo who have already engaged in a 
great deal of dialog regarding Inga language and culture revitalization, largely through the implementation of bilingual education for Inga children.

\section{References}

Albó, X. (1995). Bolivia plurilingüe: guía para planificadores y educadores. La Paz: UNICEFCIPCA.

Albó, X. (1999). Iguales aunque diferentes: hacia unas políticas interculturales y lingüísticas para Bolivia. La Paz: Ministerio de Educación, UNICEF-CIPCA.

Albó, X., \& Barrios Suvelza, F. X. (2007). Por una Bolivia plurinacional e intercultural con autonomías. La Paz: Programa de las Naciones Unidas para el Desarrollo.

Bialystok, E. (1991). Letters, sounds, and symbols: Changes in children's understanding of written language. Applied Psycholinguistics , 12, 75-89.

Bourdieu, P. (1991). Language and symbolic power. Cambridge, MA: Harvard University Press.

Canagarajah, A. S. (Ed.). (2005). Reclaiming the local in language policy and practice. Mahwah, NJ: Lawrence Erlbaum.

Carlosama Gaviria, J. A. (2001). Formación y capitación de docentes Ingas en etnoeducación - Santiago, Putumayo, Colombia. (Doctoral dissertation, Universidad Mayor de San Simón). Retrieved from http://bvirtual.proeibandes.org/bvirtual/docs/tesis/ proeib/Tesis Jesus Carlosama.pdf

Carson, J. E., Carrell, P. L., Silberstein, S., Kroll, B., \& Kuehn, P. A. (1990). Reading-writing relationships in first and second language. TESOL Quarterly, 24(2), 245-266.

Carson, J. G. (1992). Becoming biliterate: First language influences. Journal of Second Language Writing, 1(1), 37-60.

Chamot, A. U., \& O’Malley, J. (1994). The CALLA handbook. Reading, MA: Addison-Wesley.

Collier, V. P. (1987). Age and rate of acquisition of second language for academic purposes. TESOL Quarterly, 21, 617-641.

Collier, V. P. (1989). How long? A synthesis of research on academic achievement in second language. TESOL Quarterly, 23, 509-531.

Collier, V. P. 1992. A synthesis of studies examining long-term language minority student data on academic achievement. Bilingual Research Journal, 16(1-2), 187-212.

Collier, V. P. (1995). Acquiring a second language for school. Directions in Language \& Education, 1(4). Washington, DC: National Clearinghouse for Bilingual Education.

Collier, V. P., \& Thomas, W.P. (1989). How quickly can immigrants become proficient in school English? Journal of Educational Issues of Language Minority Students, 5, 26-38.

Cooper, R. (1989). Language planning and social change. Cambridge, UK: Cambridge University Press. 
Coronel-Molina, S. M. (1999). Functional domains of the Quechua language in Peru: Issues of status planning. International Journal of Bilingual Education and Bilingualism, 2(3), 166-180.

Coronel-Molina, S. M. (2005). Lenguas orginarias cruzando el puente de la brecha digital: nuevas formas de revitalización del quechua y el aimara. In S. M. Coronel-Molina \& L. L. Grabner-Coronel (Eds.), Lenguas e identidades en los Andes: perspectivas ideológicas y culturales (pp. 31-82). Quito: Abya Yala.

Coronel-Molina, S. M. (2007). Language policy and planning, and language ideologies in Peru: The case of Cuzco's High Academy of the Quechua Language (Qheswa Simi Hamut'ana Kuraq Suntur). Unpublished doctoral dissertation, University of Pennsylvania, PA.

Coronel-Molina, S. M. (2008). Language ideologies of the high academy of the Quechua language in Cuzco, Peru. Latin American and Caribbean Ethnic Studies, 3(3), 319-340.

Coronel-Molina, S. M. (2009). Definitions and critical literature review of language attitude, language choice and language shift: Samples of language attitude surveys. Bloomington, IN: Indiana University Scholar Works. Retrieved from https://scholarworks.iu.edu/dspace/bitstream/handle/2022/3785/DefinitionsCritical-Review-of-Topics-in-Sociolinguistics.pdf?sequence $=1$

Coronel-Molina, S. M., \& Quintero, V. (2010). The sociolinguistics of indigenous languages in South America. In M. Ball (Ed.), The Routledge handbook of sociolinguistics around the world (pp. 42-51). Oxford: Routledge.

Crystal, D. (2000). Language death. Cambridge, UK: Cambridge University Press.

Cummins, J. (1981). Age on arrival and immigrant second language learning in Canada: A reassessment. Applied Linguistics II, 2, 132-149.

Cummins, J. (1982). Tests, achievement, and bilingual students. Focus No. 9. Washington, DC: National Clearinghouse for Bilingual Education.

Cummins, J. (1989). Language and literacy acquisition in bilingual contexts. Journal of Multilingual and Multicultural Development, 10(1), 17-31.

Cummins, J. (1991). Interdependence of first- and second-language proficiency in bilingual children. In E. Bialystok (Ed.), Language processing in bilingual children (pp. 70-89). Cambridge, UK: Cambridge University Press.

Cummins, J. (1996). Negotiating identities: Education for empowerment in a diverse society. Ontario: California Association for Bilingual Education.

DANE. Censo General de Colombia. (2005). Retrieved from http://www.dane.gov.co/

Education Project. (2003). Proyecto educativo: Creación de la Institución Educativa Intercultural Bilingüe Inga Carlos Tamoabioy. Unpublished manuscript.

Eisterhold Carson, J., Carrell, P. L., Silberstein, S., Kroll, B., \& Kuehn, P. A. (1990). Readingwriting relationships in first and second language. TESOL Quarterly, 24(2), 245-266. 
Ethnologue. (2008). Retrieved from

http://www.ethnologue.com/show country.asp?name=colombia

Fishman, J. (1991). Reversing language shift. Clevedon, UK: Multilingual Matters.

García, M. E. (2005). Making indigenous citizens: Identity development and multicultural activism in Peru. Palo Alto, CA: Stanford University Press.

Genesee, F. (1994). Educating second language children: The whole child, the whole curriculum, the whole community. Cambridge, UK: Cambridge University Press.

Grenoble, L. A., \& Whaley, L. J. (2006). Saving languages: An introduction to language revitalization. New York: Cambridge University Press.

Hakuta, K. (1990). Bilingualism and bilingual education: A research perspective. Focus No. 1. Washington, DC: National Clearinghouse for Bilingual Education.

Harrison, B. (2005). The development of an Indigenous knowledge program in a New Zealand Maori-language immersion school. Anthropology \& Education Quarterly, 36(1), 57-72.

Harvey, P. (1994). The presence and absence of speech in the communication of gender. In P. Burton et al. (Eds.), Bilingual women: Anthropological approaches to second language use (pp. 164-179). Oxford: Berg.

Hinton, L., \& Hale, K. (Eds.). (2001). The green book of language revitalization in practice. San Diego: Academic Press.

Holm, A., \& Dodd, B. (1996). The effect of first written language on the acquisition of English literacy. Cognition, 59, 119-147.

Hornberger, N. H. (1987). Schooltime, classtime, and academic learning time in rural Highland Puno, Peru. Anthropology \& Education Quarterly, 18(3), 207-221.

Hornberger, N. H. (1988). Bilingual education and language maintenance: A Southern Peruvian Quechua case. Berlin: Mouton de Gruyter.

Hornberger, N. H. (1991). Spanish in the community: Changing patterns of language use in highland Peru. In C. A. Klee and L. A. Ramos-García (Eds.), Sociolinguistics of the Spanish-speaking world: Iberia, Latin America, United States (pp. 141-162). Arizona: Bilingual Press.

Hornberger, N. H. (1998). Language policy, language education, language rights: Indigenous, immigrant, and international perspectives. Language in Society, 27, 439-458.

Hornberger, N. H. (1999). Maintaining and revitalizing indigenous languages in Latin America: State planning vs. grassroots initiatives. International Journal of Bilingual Education and Bilingualism, 2(3), 159-165.

Hornberger, N. H. (2000). Bilingual education policy and practice in the Andes: Ideological paradox and intercultural possibility. Anthropology \& Education Quarterly, 31(2), 173-201. 
Hornberger, N. H. (2006). Voice and biliteracy in indigenous language revitalization: Contentious educational practices in Quechua, Guarani, and Maori contexts. Journal of Language, Identity, and Education, 5(4), 277-292.

Hornberger, N. H. (Ed.). (2008). Can school save indigenous languages? Policy and practice on four continents. London: Palgrave.

Hornberger, N. H., \& Coronel-Molina, S. M. (2004). Quechua language shift, maintenance, and revitalization in the Andes: The case for language planning. International Journal of Society and Language, 167, 9-67.

Hornberger, N. H., \& King, K. A. (1996). Language revitalisation in the Andes: Can schools reverse language shift? Journal of Multilingual and Multicultural Development, 17(6), 427-441.

Hornberger, N. H., \& King, K. A. (1998). Authenticity and unification in Quechua language planning. Language, culture and curriculum, 11(3), pp. 390-410.

Hornberger, N. H., \& King, K. A. (2001). Reversing Quechua language shift in South America. In J, Fishman (Ed.), Can threatened languages be saved? (pp. 166-194). Clevedon, UK: Multilingual Matters.

Howard, R. (2007). Por los linderos de la lengua: ideologías lingüísticas en los Andes. Lima, Peru: Institut Français d'Études Andines-IFEA; Instituto de Estudios Peruanos-IEP; Pontificia Universidad Católica del Perú-PUCP.

Jiang, B., \& Kuehn, P. (2001). Transfer in the academic language development of postsecondary ESL students. Bilingual Research Journal, 25(4), 417-436.

Kaplan, R. B. (1994). Language policy and planning in New Zealand. Annual Review of Applied Linguistics, 14, 156-173.

Kaplan, R. B., \& Baldauf, R. B., Jr. (1997). Language planning: From practice to theory. Clevedon, UK: Multilingual Matters.

Karam, F. X. (1974). Toward a definition of language planning. In Joshua Fishman (Ed.), Advances in Language Planning (pp. 103-124). The Hague: Mouton.

King, K. A. (2000). Language ideologies and heritage language education. International Journal of Bilingual Education and Bilingualism, 3(3), 167-184.

King, K. A. (2001). Language revitalization processes and prospects: Quichua in the Ecuadorian Andes. Clevedon, UK: Multilingual Matters.

King, K. A. (2004). Language policy and local planning in South America: New directions for enrichment bilingual education in the Andes. International Journal of Bilingual Education and Bilingualism, 7(5), 334-347.

Lewelling, V. W. (1991). Academic achievement in a second language. Washington, DC: ERIC Clearinghouse on Languages and Linguistics.

López, L. E. (2005). De resquicios a boquerones: la educación intercultural bilingüe en Bolivia. La Paz: PROEIB Andes; Plural. 
López, L. E. (2006). Cultural diversity, multilingualism and indigenous education in Latin America. In O. García, T. Skutnabb-Kangas, and M. E. Torres-Guzmán (Eds.), Imagining multilingual schools: Languages in education and globalization (pp. 238261). Clevedon, UK: Multilingual Matters.

López, L. E., \& Rojas, C. (2006). La EIB en América Latina bajo examen. La Paz: Banco Mundial; GTZ; Plural.

López, L. E., \& Sichra, I. (2008). Intercultural bilingual education among indigenous peoples in Latin America. In N. H. Hornberger (Ed.), Encyclopedia of language and education (pp. 295-309). Berlin: Springer.

McCarty, T. L. (2003). Revitalizing indigenous languages in homogenizing times. Comparative Education, 39(2), 147-163.

McCarty, T. L. (Ed.). (2011). Ethnography and language policy. New York: Routledge.

Ministerio de Educación Nacional, República de Colombia. Retrieved from http://www.mineducacion.gov.co/1621/propertyvalue-34389.html

Ricento, T. (Ed.). (2006). An introduction to language policy: Theory and method. Malden, MA: Wiley-Blackwell.

Rosier, P., \& Farella, M. (1976). Bilingual education at Rock Point-some early results. TESOL Quarterly, 10, 379-388.

Saville-Troike, M. (1998). Teaching and testing for academic achievement: Perspectives on an ill-structured domain. Unpublished manuscript.

Soler Castillo, S. (2003). Bilingüismo y actitudes lingüísticas de la comunidad indígena Inga ante el español y el inga. In A. Torres Torres (Ed.), Confines culturales y mestizaje: perspectiva histórico-geográfica. Cultura e intercultura en la enseñanza del español como lengua extranjera, monográfico de Espéculo. Barcelona: Universitat de Barcelona, Facultat de Filologia. Retrieved from http://www.ub.edu/filhis/culturele/inga.html

Swain, M. (1981). Time and timing in bilingual education. Language Learning, 31(1), 1-15.

Thomas, W. P., \& Collier, V. P. (1997). School effectiveness for language minority students. Washington, DC: National Clearinghouse for Bilingual Education.

Wright, E., \& Kuehn, P. A. (1998). The effects of academic language instruction on collegebound at-risk secondary students. Journal of Educational Opportunity, 17(1), 9-22. 